\begin{tabular}{|l|l|l}
\hline Received: October 2017 & Accepted: November 2017 & Published: April 2018
\end{tabular}

\title{
Pembuatan Alat Pengolah Limbah Cair dengan Metode Elektrokoagulasi untuk Industri Tahu Kota Samarinda
}

\author{
Eka Resky Ananda ${ }^{1^{*}}$, Dedy Irawan S.T., M.T ${ }^{2}$,Siti Dwi Wahyuni ${ }^{3}$, Anom Dwi Kusuma ${ }^{4}$, Joko \\ Buadiarto $^{5}$, Rahmat Hidayat ${ }^{6}$ \\ 1,2,3,4,5 Jurusan Teknik Kimia, Politeknik Negeri Samarinda
}

JL. DR.Ciptomangunkusumo, Sungai Keledang, Samarinda Seberang, Samarinda

E-mail: Ekarskya@gmail.com

\begin{abstract}
There are approximatel 80 home industries that producing tofu and speading in several district in Samarinda. One home-based industry can produce $30 \mathrm{~m}^{3} /$ day of liquid waste. The liquid waste is not utilized optimally and directly discharged into the environment. Liquid waste generated from the process of making tofu can demage environment due to its organic content such as COD adn TSS, which is higher than National Environmental Quality Standard. Treatment of tofu liquid waste need to be done to not damage the environmental to reduce the pollution load on the environment. One of the methods to reduce the liquid waste content is by electrocoagulated method. The process tool is aimed to decrease concentration COD of liquid waste. Tools are also designed to move dynamically from one place to another, so it can be effectively used in many places. The optimal result obtained from the treatment with his process tool is at 10 hours resulted in decreased of COD content by 77,25\% and the final concentration of liquid waste 122,88 ppm. This process tool can be applied directly and the liquid can be discharged safety into the environment.
\end{abstract}

Keywords: liquid waste, electrocoagulation, tofu

\begin{abstract}
Abstrak
Terdapat kurang lebih 80 industrirumahan yang memproduksi tahu dan tersebar di beberapa kecamatan yang ada di Kota Samarinda. Satu industri tahu rumahan dapat menghasilkan $20 \mathrm{~m}^{3} /$ hari limbah cair. Limbah cair tersebut tidak dimanfaatkan secara optimal dan langsung di buang ke lingkungan. Limbah cair yang dihasilkan dari proses pembuatan tahu, dapat merusak lingkungan karena kandungan organiknya yang lebih tinggi dari baku mutu lingkungan seperti COD dan TSS. Pengolahan terhadap limbah cair tahu tersebut perlu dilakukan agar tidak merusak lingkungan. Proses pengolahan dibutuhkan untuk mengurangi beban pencemaran pada lingkungan. Salah satu metode untuk mengurangi kandungan limbah cair tersebut menggunakan metode elektroko agulasi. Alat proses ini bertujuan untuk menurunkan konsentrasi COD limbah cair. Alat juga dirancang untuk dapat bergerak secara dinamis dari satu tempat ketempat lainnya. Sehinggadapat efektif digunakan dibanyak tempat, tidak hanya dapat mengolah limbah dari satu tempat. Hasil optimal yang diperoleh dari proses pengolahan pada alat proses ini yaitu pada waktu 10 jam menghasilkan penurunan kadar COD sebesar 97.25\% dan konsentrasi akhir limbah sebesar 122.88 ppm. Alat proses ini dapat diaplikasikan secara langsung dan aman dibuang ke lingkungan.
\end{abstract}

Kata Kunci: Limbah cair, elektrokoagulasi, Tahu

\section{PENDAHULUAN}

Tahu merupakan salah satu makanan Indonesia yang banyak dikonsumsi oleh masyarakat. Saat ini produksi tahu di daerah Samarinda masih diproduksi dalam skala rumah tangga dengan produksi sebesar 10 ton kedelai/bulan, dari data tersebut didapatkan limbah cair sebesar $20 \mathrm{~m}^{3}$ dari pengolahan [1].

Selama ini limbah tahu tidak dimanfaatkan dengan maksimal. Limbah tahu yang dihasilkan dari proses pembuatan tahu, dapat merusak lingkungan karena kandungan organiknya yang lebih tinggi dari baku mutu lingkungan seperti COD dan TSS. Pengolahan terhadap limbah cair tahu tersebut perlu dilakukan agar tidak merusak lingkungan, namun belum ada metode yang tepat dan efektif yang digunakan untuk menangani permasalahan limbah cair tahu di Samarinda. Limbah tahu mengandung BOD $(4583 \mathrm{mg} / \mathrm{L})$, COD (7050 mg/L), TSS (4743 $\mathrm{mg} / \mathrm{L})$ dan minyak/lemak (26 mg/L) [2]. Untuk itu 
dibutuhkan alat pengolah limbah cair yang dapat mengurangi pencemaran air sungai Mahakam. Pembuatan alat pengolah limbah cair industry tahu di Samarinda dibutuhkan untuk dapat mengatasi atau setidaknya mengurangi beban pencemaran sungai Mahakam.

Limbah cair yang dihasilkan dari proses pembuatan tahu biasanya dibuang secara langsung tanpa proses pengolahan terlebih dahulu, sehingga dapat mencemari lingkungan. Bila dibiarkan berlanjut air limbah akan berubah warnanya menjadi coklat kehitaman dan berbau busuk. Bau busuk ini akan mengakibatkan gangguan pernapasan. Apabila limbah ini dialirkan ke sungai akan mencemari sungai dan bila masih digunakan, maka akan menimbulkan penyakit gatal, diare, dan penyakit lainnya [4].

Proses elektrokoagulasi merupakan gabungan dari proses elektrokimia dan flokulasi-koagulasi. Proses tersebut telah dipakai untuk pengolahan limbah cair tekstil, mengatasi limbah deterjen, penanganaan limbah cair rumah potong hewan, limbah cair kopi, dan limbah cair kimiawi dari industi fiber.

Pemilihan pengolahan limbah cair secara elektrokoagulasi juga didukung penelitian penelitian sebelumnya, Penelitian Hudha dkk, . (2014) menggunakan variabel waktu elektrolisis dan voltase yang menghasilkan penurunan COD $42,11 \%$ tegangan 6 volt selama 90 menit dan TSS dapat diturunkan sampai $77,27 \%$ pada tegangan 6 volt dengan waktu elektrolisis 60 menit. Dan Hayadi dkk., (2011) menggunakan elektrokoagulasi dengan variasi waktu kontak yang menghasilkan penurunan BOD 35,53\%, COD 50,61\% dan TSS sebesar 48,94\% dengan penurunan optimal terjadi pada waktu kontak 60 menit.

Tujuan dari program ini adalah untuk mendesain dan membuat prototipe alat pengolahan limbah bergerak berkapasitas 25 liter dengan metode elektrokoagulasi filtrasi untuk penurunan COD pada limbah cair indusrti tahu Samarinda.

\section{Limbah Tahu}

Limbah cair pada proses produksi tahu berasal dari proses perendaman, pencucian kedelai, pencucian peralatan proses produksi tahu, penyaringan dan pengepresan/pencetakan tahu. Sebagian besar limbah cair yang dihasilkan oleh industri pembuatan tahu adalah cairan kental yang terpisah dari gumpalan tahu yang disebut dengan air dadih (whey). Cairan ini mengandung kadar protein yang tinggi dan dapat segera terurai. Limbah ini sering dibuang secara langsung tanpa pengolahan terlebih dahulu sehingga menghasilkan bau busuk dan mencemari lingkungan.

Pada umumnya limbah cair pabrik tahu ini langsung dibuang kesungai melalui saluransaluran. Bila air sungai cukup deras dan lancar serta pengenceran cukup (daya dukung lingkungan masih baik) maka air buangan tersebut tidak menimbulkan masalah. Tetapi bila daya dukung lingkungan sudah terlampaui, maka air buangan yang banyak mengandung bahan-bahan organik akan mengalami proses peruraian oleh jasad renik dapat mencemari lingkungan. Parameter air limbah tahu yang biasanya diukur antara lain temperatur, $\mathrm{pH}$, padatan-padatan tersuspensi (TSS) dan kebutuhan oksigen (BOD dan COD).

Karakteristik dari limbah cair industri tahu dipaparkan pada tabel 2.1 di bawah ini:

Tabel 1. Karakteristik dari Limbah Cair Industri Tahu

\begin{tabular}{llll}
\hline No. & Parameter & Satuan & Jumlah \\
\hline 1 & BOD & $\mathrm{mg} / \mathrm{L}$ & 4583 \\
\hline 2 & COD & $\mathrm{mg} / \mathrm{L}$ & 7050 \\
\hline 3 & TSS & $\mathrm{mg} / \mathrm{L}$ & 4743 \\
\hline 4 & Padatan & $\mathrm{mg} / \mathrm{L}$ & 26 \\
& Melayang & & \\
\hline
\end{tabular}

Sumber : Bangun dkk, 2013

Dari tabel 1 dapat dilihat bahwa limbah tahu mempunyai kadar limbah yang sangat tinggi karena telah melewati standar baku mutu untuk limbah tahu, yang dapat dilihat dari tabel berikut:

Tabel 2 Standar Baku Mutu Limbah Tahu

\begin{tabular}{ccl}
\hline NO & Parameter & $\begin{array}{l}\text { Kadar Maksimal } \\
(\mathrm{mg} / \mathrm{L})\end{array}$ \\
\hline 1 & $\mathrm{BOD}$ & 150 \\
\hline 2 & $\mathrm{COD}$ & 300 \\
\hline 3 & $\mathrm{TSS}$ & 100 \\
\hline 4 & $\mathrm{pH}$ & $6,9-9,0$ \\
\hline \multicolumn{4}{c}{ Sumber: Peraturan Daerah Provinsi } \\
& Kalimantan Timur No. 2 Tahun 2011
\end{tabular}

\section{Elektrokoagulasi}

Elektrokoagulasi merupakan suatu proses koagulasi menggunakan arus listrik searah melalui peristiwa elektrokimia, yaitu gejala dekomposisi elektrolit, yang kedua elektrodanya dapat terbuat dari aluminium [1]. Elektrokoagulasi beroperasi dengan penggumpalan dan pengendapan partikelpartikel halus yang terdapat dalam air dengan menggunakan energi listrik. Proses elektrokoagulasi merupakan gabungan dari 
proses elektrolisa dan proses koagulasiflokulasi. Prinsip dasar dari elektrokoagulasi menggunakan reaksi reduksi dan oksidasi (redoks). Dalam suatu sel elektrokoagulasi, peristiwa oksidasi terjadi di elektroda positif $(+)$ yaitu anoda, sedangkan reduksi terjadi di elektroda negatif (-) yaitu katoda. Dimana pada anoda terjadi pelepasan koagulan aktif berupa ion logam (biasanya Aluminium atau besi) ke dalam larutan, sedangkan pada katoda terjadi reaksi elektrolisa berupa pelepasan gas hidrogen. Adapun komponen yang terlibat dalam reaksi elektrokoagulasi selain elektroda adalah air yang diolah[2]

\section{Logam Aluminium}

Aluminium merupakan salah satu logam anorganik yang dijumpai dalam air minum. Aluminium juga merupakan salah satu elektroda yang dapat digunakan dalam proses elektrokoagulasi karena nilai konduktivitasnya yang cukup tinggi sehingga dianggap baik untuk menghantarkan muatan- muatan listrik dalam proses tersebut [3]. Aluminium digunakan sebagai koagulan dalam pengolahan limbah[4]Proses elektrokoagulasi melibatkan logam aluminium yang menghasilkan ion $\mathrm{Al}^{3+}$ untuk ditambahkan ke limbah sebagai koagulan. Jika proses kimia sebagai koagulannya berupa kation aluminium hasil elektrokoagulasi maka sludge yang dihasilkan secara teoritis lebih kecil dibandingkan dengan koagulan aluminium sulfat pada reaksi dengan surfaktan $\left(\mathrm{Al}_{2}\left(\mathrm{SO}_{4}\right)_{3} \cdot 4 \mathrm{H}_{2} \mathrm{O}\right)$. Hasil sludge juga lebih aman karena tidak mengandung sulfat atau klorida, sehingga lebih mudah penanganannya dibanding dengan memakai koagulan aluminium sulfat atau Poly Aluminium Chlorida (PAC). Besar kecilnya ion $\mathrm{Al}^{3+}$ yang dihasilkan dari elektrolisa logam aluminium sangat tergantung pada besar kecilnya sifat elektrolit dan/ atau TSS, sulfat dan klorida dari limbah yang diolah [4].

\section{METODOLOGI}

Perancangan dan pembuatan alat pengolah limbah cair bergerak dimulai dengan tahap desain alat proses, dilanjutkan dengan pembuatan alat proses. Selanjutnya dilakukan pengujian alat dan penyesuaian kondisi proses maksimum menggunakan sampel limbah cair industri tahu.

Desain prototipe alat dibuat menjadi alat proses pengolahan limbah cair bergerak tersaji pada lampiran. Prototipe alat yang dibuat berbahan utama kaca dengan ketebalan $5 \mathrm{~mm}$. Pada bak pertama terdapat 5 sel. Alat dilengkapi dengan roda dibagian bawah agar mudah dalam pergerakannya. Alat juga dilengkapi dengan alat pengatur tegangan listrik yang digunakan untuk proses elektrokoagulasi.

Pengukuran COD dan $\mathrm{pH}$ sebelum dan sesudah proses akan di analisa menggunakan analisa COD dan $\mathrm{pH}$ meter yang tersedia di dalam lab. Teknik Kimia Politeknik Negeri Samarinda.

\section{HASIL DAN PEMBAHASAN}

Alat pengolah limbah cair dengan metode elektrokoagulasi filtrasi telah selesai dibuat dan telah uji coba dan alast bekerja dengan baik.

Tabel 3 Hasil analisa Limbah Tahu

\begin{tabular}{|c|c|c|c|c|}
\hline \multirow{2}{*}{$\begin{array}{l}\text { Waktu } \\
\text { Tinggal } \\
\text { (jam) }\end{array}$} & \multicolumn{2}{|c|}{ Konsentrasi (ppm) } & \multirow{2}{*}{$\begin{array}{c}\text { Persen } \\
\text { Removal } \\
(\%)\end{array}$} & \multirow{2}{*}{$\mathrm{pH}$} \\
\hline & $\begin{array}{l}\text { Sebelum } \\
\text { Proses }\end{array}$ & $\begin{array}{l}\text { Setelah } \\
\text { Proses }\end{array}$ & & \\
\hline 6 & 4423,68 & 1556,48 & 64,81 & 5,2 \\
\hline 7 & 4505,6 & 942,08 & 79,09 & 5,6 \\
\hline 8 & 4136,96 & 573,44 & 86,14 & 5,9 \\
\hline 9 & 4218,88 & 327,68 & 92,23 & 6,4 \\
\hline 10 & 4464,64 & 122,88 & 97,25 & 6,7 \\
\hline
\end{tabular}

\section{Pembahasan}

Penelitian ini bertujuan untuk mendesain dan membuat prototipe alat pengolahan limbah bergerak berkapasitas 25 liter dengan metode elektrokoagulasi filtrasi untuk penurunan COD pada limbah cair indusrti tahu Samarinda. Pada penelitian ini, limbah cair tahu diperoleh dari salah satu pabrik di Palaran. Pada analisa awal limbah cair tahu yang terdapat pada tabel 3 menunujukkan bahwa limbah cair tahu sebelum diolah menggunakan proses elektrokoagulasi berada diluar standar baku mutu berdasarkan Peraturan Menteri Lingkungan Hidup RI No. 5 Tahun 2014, dimana variabel respon yang diuji untuk COD sebesar 2800,896 ppm, TSS sebesar $818 \mathrm{mg} / \mathrm{L}$ dan $\mathrm{pH} 3,80$. Oleh sebab itu, perlunya pengolahan limbah cair tahu sebelum dibuang ke lingkungan sekitar.

Pembuatan prototipe alat pengolah limbah bergerak dimulai dari tahap pembuatan desain alat dan dilanjutkan dengan pembuatan alat proses. Bahan utama yang digunakan dalam pembuatan prototipe alat ini adalah kaca dengan ketebalan $5 \mathrm{~mm}$. Pemilihan kaca sebagai bahan untuk pembuatan alat ini 
dikarenakan beberapa keunggulan yang dimiliki oleh kaca yaitu transparan dan tidak menghantarkan listrik. Jika dibandingkan dengan bahan transparan lainnya misalnya akrilik, kaca memiliki harga yang lebih murah. Selain itu akrilik mudah tergores, cepat kotor dan buram/kusam dalam waktu lama. Sebagai penopang kaca digunakan sebuah rangka besi yang dilengkapi dengan roda di bagian bawah agar mudah dalam pergerakannya. Secara keseluruhan alat berukuran $156 \mathrm{~cm}$ x $100 \mathrm{~cm}$.

Bak pertama berfungsi sebagai tempat terjadinya proses elektrokoagulasi. Pada bak pertama ini dilengkapi dengan sebuah adaptor pengatur tegangan listrik yang digunakan pada proses elektrokoagulasi. Bak pertama berukuran $30 \mathrm{~cm}$ x $33 \mathrm{~cm}$ x $42.5 \mathrm{~cm}$ (p x 1 x t). Ukuran tersebut dibuat untuk menyesuaikan volume limbah yang digunakan yaitu sebanyak 25 L. Tinggi air limbah pada volume tersebut berada pada ketinggian $33 \mathrm{~cm}$ dari dasar bak. Sisa tinggi yang tersisa digunakan untuk jarak pada penggunaan kabel sebagai penggantung plat alumunium. Plat tersebut digunakan sebagai elektroda pada proses elektrokoagulasi. Pada alat proses ini dibagi menjadi 5 sel yang setip selnya berukuran volume 5 liter dengan setiap selnya menggunakan 2 buah plat alumunium. Pembagian menjadi 5 sel ini dikarenakan agar keseluruhan limbah mengalami proses elektrokoagulasi secara merata. Lebar setiap selnya adalah $5 \mathrm{~cm}$ dengan jarak antar plat adalah $3 \mathrm{~cm}$. Pada dinding terakhir bak pertama terdapat 1 buah valve berdiameter 0.75 inch dan 1 buah keran kecil disetiap selnya.

Pada proses elektrokoagulasi, $\mathrm{NaOH}$ digunakan sebagai elektrolit untuk menghantarkan arus listrik. Sifat $\mathrm{NaOH}$ sebagai elektrolit kuat akan mengakibatkan $\mathrm{NaOH}$ terionisasi sempurna di dalam air menjadi $\mathrm{Na}^{+}$dan $\mathrm{OH}^{-}$, sehinga hasil reaksi ionisasi dari $\mathrm{NaOH}$ akan menghantarkan arus listrik pada elektrode. Pada penelitian ini elektrode yang digunakan adalah aluminium dimana elektrode bagian sisi anode akan mengalami oksidasi membentuk $\mathrm{Al}^{3+}$ dan pada sisi katode air $\left(\mathrm{H}_{2} \mathrm{O}\right)$ akan mengalami reduksi dan terbentuk gas $\mathrm{H}_{2}$ dan $\mathrm{OH}^{-}$. Sehingga dari hasil reaksi pada anode dan katode akan terjadi reaksi dimana kompleks $\mathrm{Al}^{3+}$ akan bereaksi dengan $\mathrm{OH}^{-}$membentuk alumunium hidroksida $\mathrm{Al}(\mathrm{OH})_{3}$. Dalam proses elektrokoagulasi $\mathrm{Al}(\mathrm{OH})_{3}$ berfungsi sebagai koagulan yang akan menggabungkan polutan yang terdapat dalam limbah cair tahu. Dimana $\mathrm{Al}(\mathrm{OH})_{3}$ akan mendestabilisasi partikel kolid, kemudian proses netralisasi muatan pada koagulan terhadap partikel koloid akan berlangsung. Sehingga akan terjadi gaya tarik menarik patikel yang berlawanan muatan untuk mendorong terjadinya agregasi koloid dan zat-zat tersuspensi halus. Partikel koloid yang telah bergabung membentuk microflok, kemudian ukuran dari flok-flok akan semakin membesar selama proses elektrokoagulasi berlangsung dan pada akhirnya akan mengendap. Pada penelitian ini, endapan terlihat banyak mengendap pada sisi anode. Hal ini disebabkan $\mathrm{Al}^{3+}$ terbentuk pada sisi anode. Banyaknya polutan yang berupa zat organik dan anorganik serta partikel suspensi yang saling bergabung dan kemudian mengendap maka menyebabkan kandungan COD dan TSS yang terdapat dalam limbah cair tahu menurun.

Hasil proses yang keluar dari bak pertama akan difiltrasi terlebih dahulu sebelum masuk ke bak kedua. Proses filtrasi ini menggunakan bantuan kapas filter untuk menyaring flok-flok yang terbentuk pada proses elektrokoagulasi maupun partikelpartikel pengotor yang terdapat di dalamnya. Untuk menyangga kapas filter digunakan kawat penyaring sehingga tidak mudah bergerak karena aliran air yang keluar dari bak pertama. Di bawah kawat penyaring ini, terdapat sebuah kaca yang dipasang miring dengan panjang $25 \mathrm{~cm}$ agar air yang telah difiltrasi jatuh pada bagian awal dasar bak kedua. Bak kedua ini memiliki ukuran $31.5 \mathrm{~cm}$ x $33 \mathrm{~cm} \mathrm{x} 49 \mathrm{~cm}$ (p x 1 x t). Pada dasar bak ini, terdapat kaca-kaca yang dibuat miring dengan ukuran $2.5 \mathrm{~cm}$ x $33 \mathrm{~cm}$ sebanyak 6 buah. Kaca-kaca tersebut akan menghambat aliran air menuju bak ketiga serta mengendapkan partikel-partikel pengotor yang tidak tersaring pada proses sebelumnya.

Air yang telah melalui proses pada bak pertama dan kedua akan menuju bak ke tiga melalui celah dengan tinggi $5 \mathrm{~cm}$ pada dinding akhir bak ke dua. Bak ketiga berfungsi untuk memfiltrasi kembali dengan sand filter . Bak ketiga ini berukuran $29 \mathrm{~cm}$ x $33 \mathrm{~cm}$ x $50 \mathrm{~cm}$, dengan sebuah keran berdiameter 0.71 inch pada bagian dasar bak sebagai tempat keluar air dan terdapat kren keluar ke penambungan hasil. Untuk melihat kinerja dari alat ini dilakukan percobaan dengan memvariasikan waktu proses. Konsentrasi akhir dari limbah 
zat warna yang telah diproses digunakan sebagai tolak ukur keberhasilan alat proses ini.

Untuk melihat pengaruh lama waktu proses terhadap effisiensi alat dibuat grafik hubungan antara effisiensi alat dan waktu proses.

\section{waktu proses vs effisiensi alat}

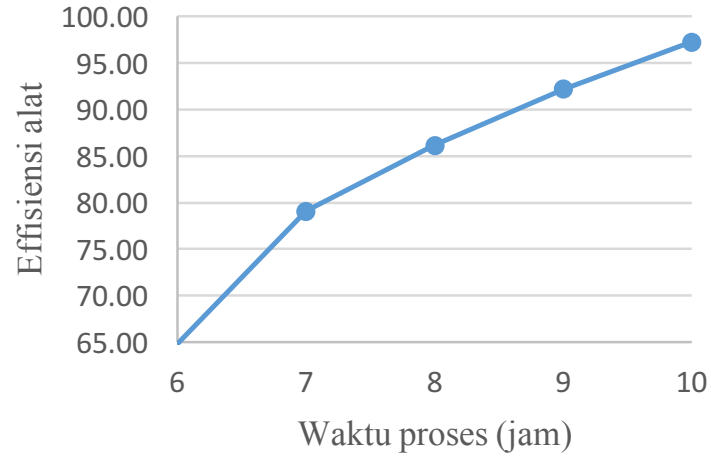

Gambar 1 Hubungan antara effisiensi alat dengan waktu proses

Berdasarkan gambar 4.5, dapat dilihat bahwa semakin lama waktu proses elektrokoagulasi maka semakin besar penurunan kadar COD yang dihasilkan. Hal ini disebabkan karena pembentukan $\mathrm{H}_{2}$ dan $\mathrm{OH}^{-}$semakin banyak sehingga semakin banyak pula jumlah kompleks yang mengikat polutan. Dengan demikian jumlah polutan dalam larutan akan semakin berkurang. Hal ini juga sesuai dengan hukum Faraday I yang menyatakan bahwa "massa zat yang dihasilkan di elektroda selama proses elektrolisis berbanding lurus dengan banyaknya mol elektron (kuantitas kelistrikan) yang diberikan ke elektroda". Berdasarkan hukum tersebut diketahui bahwa jika semakin besar waktu yang digunakan untuk proses elektrolisis maka total muatan yang dihasilkan juga semakin besar. Hal ini menyebabkan massa zat yang dihasilkan di elektroda juga semakin besar. Semakin besar massa zat yang dihasilkan di elektroda menyebabkan penurunan konsentrasi limbah menjadi semakin besar. Namun karena kemampuan elektroda dalam mereduksi air limbah terbatas, maka meskipun waktu kontak diperlama reaksi antara elektroda dengan air limbah sudah jenuh sehingga kemampuan elektrodanya berkurang. Dapat dikatakan kinerja plat telah mengalami kejenuhan. Dari seluruh data-data yang telah disebutkan, terlihat bahwa proses elektrokoagulasi dengan tegangan 2 volt dan waktu proses selama 10 jam akan memberikan hasil yang optimum yaitu penurunan konsentrasi COD sebesar 97.25\% dengan konsentrasi akhir limbah 122.88 ppm, hasil yang diperoleh telah memenuhi standar baku mutu lingkungan menurut Peraturan Daerah Provinsi Kalimantan Timur No. 2 Tahun 2011 sehingga alat proses ini dapat diaplikasikan secara langsung dan aman dibuang ke lingkungan.

\section{KESIMPULAN}

Alat ini terdiri dari 3 buah bak yang dilengkapi dengan elektroda dan adaptor. Bak pertama digunakan sebagai tempat berlangsungnya proses elektrokoagulasi, bak kedua digunakan sebagai tempat filtrasi dan bak ketiga bak sand filter. Hasil optimal yang diperoleh dari proses pengolahan pada alat proses ini yaitu pada waktu 10 jam dengan tegangan sebesar 2 volt menghasilkan penurunan kadar COD sebesar 97.25\% dan konsentrasi akhir limbah sebesar 122.88 ppm. Alat proses ini dapat diaplikasikan secara langsung dan sesuai dengan target yang diinginkan

\section{SARAN}

Menggunakan pompa untuk memasukkan limbah ke bak 1. Mencari alternatif lain untuk pembuangan ada bak 1 .

\section{UCAPAN TERIMAKASIH}

Puji syukur kami panjatkan kehadirat Allah SWT yang telah memberikan rahmat dan hidayah-Nya sehingga kami dapat menyelesaikan laporan akhir Program Kreativitas Mahasiswa pada bidang kegiatan Karsa Cipta (PKM-KC) dengan judul "Pembuatan Alat Pengolah Limbah Cair Dengan Metode Elektrokoagulasi Untuk Industri Tahu Kota Samarinda”. Ucapan rasa terimakasih kami sampaikan kepada Bapak Dedy Irawan, ST., MT. selaku dosen pembimbing yang selalu memberikan arahan dan masukan kepada kami, sehingga pelaksanaan kegiatan PKM-KC ini dapat berjalan dengan lancar. Tidak lupa kami ucapkan rasa terimakasih kepada Direktorat Jenderal Pendidikan Tinggi yang telah memberikan bantuan dana bagi pelaksanaan PKM-KC ini. Serta rasa terimakasih juga kami sampaikan kepada semua pihak yang telah membantu dalam pelaksanaan PKM-KC ini. Atas segala bantuannya, kami ucapkan terimakasih Dalam pembuatan laporan akhir ini, kami memohon maaf atas segala kesalahan dan kekurangan yang ada. Kami berharap 
laporan ini dapat berguna bagi pembaca dan masyarakat luas yang membutuhkan. Serta laporan ini dapat dijadikan referensi guna penelitian yang akan datang. Terima kasih

\section{DAFTAR PUSTAKA}

[1] A. Allo, "Pengaruh Loading Rate Terhadap Penurunan Kadar COD dan TSS," Politeknik Negeri Samarinda, Samarinda, 2015.

[2] A. Bangun, S. Aminah, R. Hutahean and M. Ritonga, "Pengaruh Kadar Air, Dosis dan Lama Pengendapan Koagulan Serbuk Biji kelor Sebagai Alternatif Pengolahan Limbah Cair Industri Tahu," Jurnal Teknik Kimia, vol. 2, no. 1, pp. 7-13, 2013.

[3] A. Yulianto, L. Hakim, I. Purwaningsih and V. Pravitasari, "Pengolahan limbah cair industri batik pada skala laboratorium dengan menggunakan metode elektrokoagulasi," Jurnal Teknologi Lingkungan Universitas Trisakti, pp. 6-11, 2009.

[4] B. Iswanto, "Teknologi elektrokoagulasi hasil penelitian untuk pengolahan limbah domestik," Jurnal teknologi Lingkungan Universitas Trisakti, vol. 5, no. 4, pp. 1-9, 2010.

[5] F. Kaswinarni, "Kajian teknis Pengolahan Limbah Padat dan cair Industri Tahu," Fakultas Ilmu Lingkungan Universitas Diponegor, Semarang, 2007.

[6] G. Pillay, "Industrial Electrolysis and Electrochemical Engineering (general), Issue 9 Volume 6, Issue 9 of ECS transactions," 2007. [Online]. Available: https://books.google.co.id/books? $\mathrm{id}=\mathrm{oZy} 6$ YH1IZcC\&pg=PA14\&dg=Futuree+for + electrtocoagulation + as $+\mathrm{A}+$ Localised + Wat er+Treatment + TEchnology $\& h l=e n \& s a=X$ \&ved=0ahUKEwjS5ryiy9DJAhXHipQK HYtECjMQ6AEIzAJ\#v=onepage\& $\mathrm{q}=$ elec trocoagulation $\& \mathrm{f}=$ false.

[7] Lembaga Derah Provinsi Kalimantan Timur, "Peraturan Daerah Provinsi Kalimantan Timur Nomor 02 Tahun 2011 Tentang Pengelolaan Kualitas Air dan Pengendalian Pencemaran Air," Kalimantan Timur, 2011.

[8] M. Hudha, Jimmy and Muyassaroh, "STUDI PENURUNAN COD DAN TSS LIMBAH CAIR INDUSTRI TAHU MENGGUNAKAN
ELEKTROKIMIA," Fakultas Teknologi Industri Institut Teknologi Nasional Malang, Jawa Timur, 2014.

[9] N. Hayadi, E. Sutrisno and S. Sumiyati, "Analisis Penyisihan Kadar COD, BOD dan TSS," Universitas Diponegoro, 2011.

[10] R. Noviatri, "penerapan metode elektrokoagulasi dalam pengolahan limbah cair industri karet dengan menggunakan elektroda aluminium," Politeknik Negeri Sriwijaya, Palembang, 2014. 